\title{
The Digital Revolution in Scholarly Editing
}

Peter Robinson

University of Saskatchewan, Canada

It is now a standard topic (even, a meme) in the discourse of textual scholarship to speak of the revolution in our profession occasioned by digital methods. The technology that brought us those methods also brought us Google. A search on "Digital revolution in textual scholarship" brings us over four million results, dispersed across multiple scholarly areas: the Greek New Testament, medieval vernacular poetry, nineteenthcentury English poetry, Sanskrit epics, modernist literature. ${ }^{\mathrm{I}}$ Of course, as academics, we do not all agree. Just to use the word "revolution" is to cast provocations upon the waters - some will say: of course it is a revolution; others will say, no it is not. In this article I argue that the changes we may see in scholarly editing may amount to a revolution. However, the reasons I think it may be a revolution differ from those usually given. Further, I think the effects of this revolution may reach far further than is usually supposed. Indeed, this revolution may be "revolutionary".

\section{Is access to manuscript images a "fast" revolution?}

De Toqueville, the founder of modern discussions of revolution, distinguished between "fast" revolutions — political and suddenand "slow" revolutions, which might take generations, but achieve a complete transformation of society. ${ }^{2}$ One could argue that the sudden and astonishing availability of millions of images of manuscripts and books online is a "fast" revolution. Before this, if you wanted to know what the Beowulf Manuscript or a Shakespeare First Folio looked like you had to find a book with an image. Usually, the book offered one

This lecture was given on 9 December 20I4 at Stockholm University.

How to cite this book chapter:

Robinson, P. 20I6. The Digital Revolution in Scholarly Editing. In: Crostini, B., Iversen, G. and Jensen, B. M. (eds.) Ars Edendi Lecture Series, vol. IV. Pp. I 8 I-207. Stockholm: Stockholm University Press. DOI: http://dx.doi.org/Io.I6993/baj.h. License: CC-BY 4.० 
and only one image, and that in shades of grey. ${ }^{3}$ Now, the whole of the Beowulf manuscript is online, freely available and just a few clicks away, and in full colour too. ${ }^{4}$ One can find not just one first folio online, but many more, and few weeks go by without an announcement, that library A is putting a new collection of manuscripts online. It used to be that you needed special permission to see a whole manuscript online, or deep pockets to pay for a facsimile or commission a set of photographs. In twenty-five years up to 8 July 2009 the British Library allowed only four scholars to inspect the 347 leaves of the great $4^{\text {th }}$-century Codex Sinaiticus in their possession. ${ }^{5}$ On that day, images of the whole manuscript went online and were seen by over a million people in the next few months. Surely, this is a revolution, and a very fast one.

Fast: but not a revolution. A few years ago, my successor as Professor of Textual Scholarship at De Montfort University, Leicester, Tony Edwards, declared to an audience of textual scholars and digital humanists that the digital revolution had really changed nothing in textual scholarship. ${ }^{6}$ All it meant, he argued, was that we could now look at digital images online, rather than having to go to the British Library. It made matters more convenient, like travelling on a faster train or bus. But it did not amount to a revolution. Nothing fundamental was changed. I agree with Professor Edwards. There are numerous scholars and others who declare that to have all the manuscripts, all the books of the world online, is revolutionary. We are giving access to everyone, for just the cost of an internet connection, to materials which used to be available only to the most privileged of scholars. Everyone can now wake up in the British Library. ${ }^{7}$

However, providing access changes nothing, of itself. If people actually use that access to make new editions, new scholarship, of a kind never seen before, which readers may use in ways never known before, then that would indeed be a revolution. But this has not happened. We now have thousands of manuscripts and millions of books online. And what are people doing with all this? The language used to describe these collections is revealing: in almost no case, are these abundances of materials described as "editions". They are "archives", "thematic research collections", perhaps "arsenals", but not editions. ${ }^{8}$ Indeed, looking over many of these collections, such as the manuscript image collections in Manuscriptorium, in e-Codices, in Bavarian State Library initiatives, not to mention the millions of books in Google Books, 
the Hathi Trust, in Europeana - none of these could in any way be called editions. One presumes in editions at least a minimum level of scholarly intervention, in selection of material, in the provision of transcriptions, annotations and commentary. These are almost entirely absent from these collections. These look like nothing so much as the vast microfilming endeavours of the last century: updated to glossy digital, usually packaged in manners which put the creating and funding institutions in the best possible light, but still nothing more than the raw material of scholarship. As Edwards argued, the digital world only makes these more accessible. No revolution in that.

However, digital methods are being used to create many objects which are indeed editions. Perhaps, these might qualify as the components of a fast revolution. Consider the many editions made with Stefan Hagel's “Classical Text Editor” software, or with Wilhelm Ott's TUSTEP system. A glance shows these are remarkably familiar. There is a base text which appears at the top of the page. Below are layers of apparatus: reporting variants in many witnesses, references to sources, editorial notes. Scholarly introductions and appendices top and tail the edition. Further: these editions are commonly published in book form by exactly the same publishers who have, for centuries in some cases, been publishing scholarly editions. ${ }^{9}$ They are made by the same community, of tenured academics, of doctoral students and postdoctoral researchers within the academy, which has produced books looking just like this, published (often with handsome government subventions) by the same presses, and destined for the same shelves in the same university libraries where they wait for years to be discovered by an avid reader who will treasure what they offer. We could celebrate that such editions can now be made with a facility never before possible, and celebrate too that the highest standards of meticulous textual scholarship are being maintained into the digital era. We could also take comfort of the reassuring persistence of the authority of the academy in the structures underlying these editions. They are made only by those qualified to make them, published only by presses which understand the value of what they are publishing. We could congratulate ourselves, that we can make more such editions, more conveniently. But this would not be a revolution.

Arguments such as these have led commentators as diverse as Thomas Tanselle and Barbara Bordalejo to assert that indeed, the digital revolution has not changed the fundamental model of scholarly editing. ${ }^{\text {10 }}$ An edition is an edition, an editor is an editor, and that is that. If in the 
digital world, we do not change what we do, we do not change what we make, we do not change who we are: there is no revolution. I agree with Tanselle, Bordalejo and Edwards: there is no revolution in digital editing. Not now. Not yet. But there could be such a revolution. I contend that in the next years what we do as editors may change. The editions we make may change. And most radically of all, who we are may change. Indeed, I think this is already happening. Let us consider each of these in turn: what we do; the editions we make; and who we are.

\section{Elements of a revolution: changing what we do}

In approximate order of difficulty, we may deal first with the first: what we do. I have already said, that the provision of masses of digital images online does not constitute any kind of revolution. If we do nothing with those images, nothing happens. But some of us are doing things with these digital images. We might transcribe the text of those manuscript images. Transcription of original materials is in itself hardly novel or revolutionary. But the digital medium is leading us into areas where we are having to think about what we do, as editors, in ways we have never had to think about before. Consider the simple noun, transcription. It sounds simple enough: you look at the manuscript and you record what you see. As two decades now of scholars making digital transcripts of original textual materials have discovered, it is not so simple at all. ${ }^{\text {II }}$ A single manuscript page contains an almost limitless number of signs. Consider the first page of the Hengwrt manuscript of Geoffrey Chaucer's Canterbury Tales, now in the National Library of Wales, and probably the oldest surviving manuscript of the Canterbury Tales. ${ }^{\mathrm{I2}}$ We see ornamentation in the left margin and a decorative capital, part of the page torn or eaten away (perhaps by rats) at the top, text in different inks and possibly written by different scribes at different times, text in margins, erasures or holes or other gaps, heavy staining on the right hand bottom corner. This even before we start on transcription of the page: whereupon we discover that a letter in the fourth line of the page (on Figure I, left), which we confidently transcribe as the letter " $\mathrm{s}$ ", is actually very different from this letter "s" in the seventh line (Figure I, right).

Should we not record this difference? And indeed, the differences among all the forms of all the letters? And of course: all the marks upon the page, the staining, the marginalia. Should we not record all these, too? In the world of print, there was no need for these decisions. An "s" was an "s"; the editor might offer a note here and there about staining, 

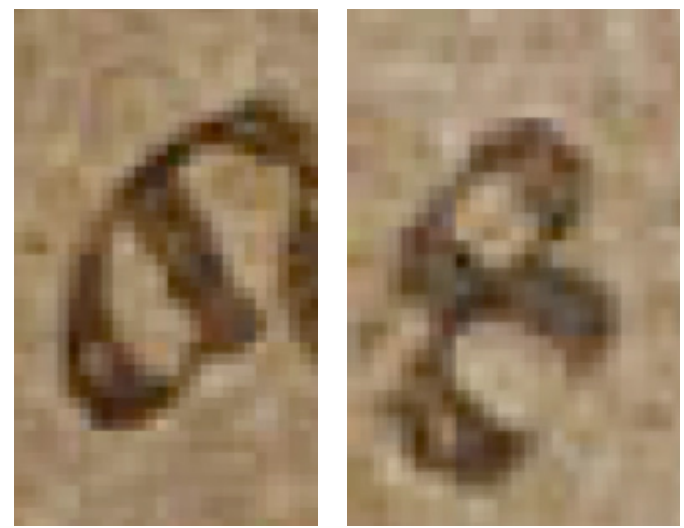

Figure 1. Two forms of the letter "s" from the first page of the Canterbury Tales in the Hengwrt manuscript

rats and wormholes. But now: one can contemplate the possibility of recording all the forms of every letter; the precise point on every page where the text lies; the exact sequence of writing of the text, letter by letter, as painstakingly constructed by the editor.

One might question the intellectual justification for such minute analysis: that we can now perform such prodigies does not mean that we should. Perhaps so. But even to consider these matters shows that how we see text in primary sources in the digital age has changed. Consider Figure 2:

From the context we know this should be the word "down". It appears that we have here an excellent instance of the use of macron over the letter $\mathrm{u}$ to indicate abbreviation of a nasal. Accordingly, we might transcribe the word straightforwardly as dou[n], and encode the macron as an

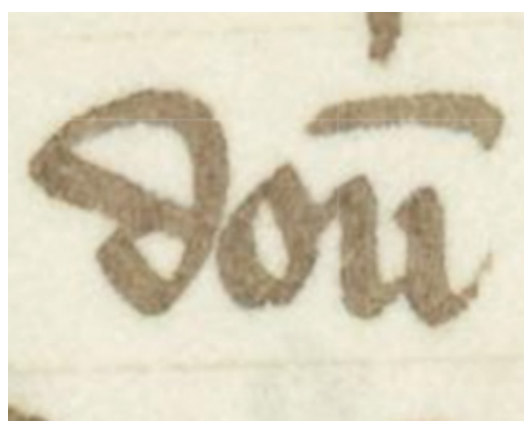

Figure 2. "doun" (modern "down") from Corpus Christi College Oxford MS I98 (Cp) (Cp) fol. 54r, Miller's Tale 633 
abbreviation of $\mathrm{n}$. This is in perfect accord with the textbook account of a macron over final $u$ as an abbreviation of final $n$. If all we were doing was looking at this single word in this manuscript we would see no problem here at all. But in the transcriptions we are making, we are not looking just at this word in this manuscript —as we might do, if all we were doing was looking for variants from a base text, and quarrying occasional readings from the manuscript. Instead, we find ourselves looking at every word: at every case where we see a macron over something which might be a $\mathrm{u}$. And what we see undermines our certainty.

While in the third, fourth and fifth examples of Figure 3 it might be possible to interpret the macron as an abbreviation of a final $/ \mathrm{n} /$ (which requires that we interpret the final two minims as $/ \mathrm{u} /$ ), in the first and second examples the /un/ is written out in full and the macron cannot represent an abbreviation. Indeed, this is the usual case. Thousands of times, as Figure 4 shows for spellings of "whan" and "when", we find "when", "in”, "upon”, "slepen”, "been”, where there is a macron over the final two minims, which must represent $/ \mathrm{n} /$ and hence the macron must be simply decorative.

Indeed, we discover that scribes, over and over, don't seem to care whether the two minims are joined at the top (as in a modern printed $\mathrm{n}$; the second example in Figure 4 ) or joined at the bottom (as in a modern printed $u$; the third example in Figure 4), or not joined at all (the first example in Figure 4). And then, what we call a macron takes a bewildering variety of forms. Sometimes it is indeed a single straight
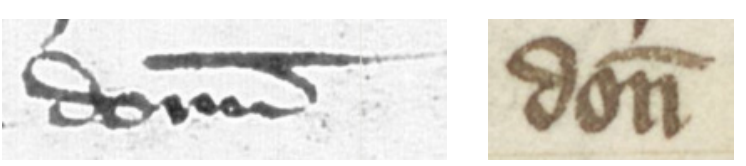

Figure 3. other representations of "doun": from Cambridge, Fitzwilliam Museum McLean MS I8 I (Fi) fol. 8r, General Prologue 395; Cp fol. 37v, Knight's Tale I797; Cp fol. 29v, Knight's Tale i I96; Cp fol. 2or, Knight's Tale 5i9; Cp fol. 29v, Knight's Tale I I96

\section{D) fan}
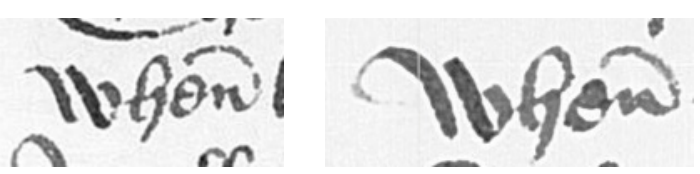

Figure 4. Three forms of "whan/wben" from the Fitzwilliam manuscript: folios 2r, General Prologue ; I6r, Knight’s Tale 36; I7v, Knight's Tale I 43. 
stroke over the letter. Sometimes it extends over several letters. Often it is curved. And very often it appears as a loop, beginning at the base of the last minim and arching back over the two minims of the $\mathrm{u} / \mathrm{n}$ character and preceding letters. Attempting to devise transcription protocols in these circumstances is a complex dance with a collection of hydra. The intentions of the scribes appear increasingly opaque and distant, and we are left searching our own intentions. Exactly what are we trying to record; for who; and why? ${ }^{\text {13 }}$ Our answer is that our transcripts are our best guess at how the manuscripts might most usefully be read. This is a far less confident assertion than to say (for example) that our transcription aims "to record the appearance of the text in the manuscript" (Digital Scriptorium guide, see fn. Io) or "to give a truthful representation of what the writer actually wrote" (Low Country Digital Library Transcription Manual, 20I3, p.2 at http://lcdl. library.cofc.edu/sites/default/files/lcdldocumentation/TranscriptionManual-LCDL-20I3.pdf). Nonetheless, it is the furthest we feel we can go. We have considered the uses we might make of the transcriptions, and tried to imagine how others might use them, and transcribed the documents accordingly.

The complexity of our task is a direct result of our decision to transcribe the whole text of each manuscript into digital form. If we were simply picking a few readings here and there from the manuscripts, we would not have these problems. Why go to all this effort? For us, the difficulty is the reason. It is difficult because we find we are struggling to understand the writing practices of the scribes and the conventions which govern the presentation of the manuscripts. It is from this close engagement with difficult problems that new knowledge arises. It is easy to look at the manuscripts from a distance and think you understand all you see. However, transcription in the digital medium has forced us to look very closely at the manuscripts and we are puzzled by what we see. Already, we understand more than we did about what scribes do. We see the extent to which convention governs much of their practice; we see too how conventions change from scribe to scribe. As more and more manuscripts are transcribed, new questions and new knowledge will arise. Most certainly, we do not transcribe manuscripts in the digital era as we might have done a century ago, and we do not look at manuscripts the same way. ${ }^{14}$

There is a very concrete way in which our full transcription of manuscripts into digital form has changed what we do. Traditionally, manuscripts have been foliated - had their pages numbered - in a very 
simple way. The cataloguer numbers the first surviving folio as " $I$ " (usually writing " $\mathrm{I}$ " in the top right of the recto), numbers the next one " 2 ", and carries on to the last surviving folio. This has advantages. It provides an unambiguous way of referring to each folio and it can be done without having to spend any time looking at the contents or structure of the manuscript. If the task is to foliate a large number of manuscripts, and if there is only a limited time to do this work, this is the clearly the best way to proceed: hence the very large number of manuscripts foliated by this method. But in projects such as ours, where we are transcribing the full text of the manuscripts, this leads to odd results. Consider two manuscripts of the Canterbury Tales, the Hengwrt manuscript, Peniarth 392D at the National Library of Wales $(\mathrm{Hg})$ and British Library Sloane MS I686 (Sl2). Earlier, I referred to the first page of the text of the Hengwrt manuscript $(\mathrm{Hg})$. This page is traditionally numbered " 2 " because at some point in the history of the manuscript, someone decided to bind a quite unrelated single leaf from a musical manuscript in front of this first page. So this single leaf became "I", and the first page of the Tales, which was also the first page of the first regular quire of 8 , became " 2 ". In contrast, the Sl2 manuscript of the Tales has lost its first page (as analysis of the quire shows), and hence the text of the Tales commences at line 63 . However, in this case traditional foliation awards this page the number "I", although this was not the original first page of the manuscript. The result is puzzling. It appears from the foliation as if something is missing from the beginning of Hengwrt, while nothing is missing from S12. In fact the reverse is the case.

Nor are these isolated cases. Of the eighty-four manuscripts holding the Tales, just seven are exactly now as they were five or six hundred years ago, with no pages lost, no pages added, no pages moved. For these seven, the traditional foliation is perfectly satisfactory. For the other 77 , it is misleading, sometimes profoundly so. Accordingly, we have long wanted to change how we foliated the manuscripts. Our aim is to show how pages have been lost, added, and reshuffled. You can see the results of this in our foliation of the Hengwrt manuscript. First, we start our foliation at I, not 2, ignoring the unrelated singleton added later at the beginning of the manuscript. Second, three whole quires, beginning with folio I99, have been moved from late in the manuscript so they now come between folios 86 and 87 . Third, a single sheet which we label I 27 a has been placed between folios I 27 and I 28 . Fourth, a whole ten folio quire has been inserted between folios I 37 and I3 8: we label these 


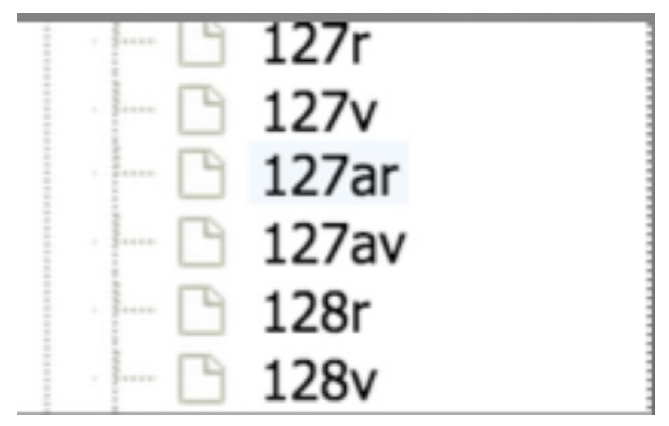

Figure 5. Foliation of folios $\mathrm{I}_{2} 7$ through I 28 , showing the added singleton leaf ( $127 \mathrm{a})$.

folios as I 37 a I through I 37 a Io. Finally, the foliation goes from I98 to 223 because, as we have seen earlier, the three quires holding folios 199 to 222 have been moved to between folios 86 and 87 . Figure 5 shows how, according to these principles, we foliate the sequence I $27 \mathrm{~V}, \mathrm{I} 27 \mathrm{a}$ (the singleton inserted after I27) and I28:

There are several benefits in this refoliation. First, it immediately informs the reader that the manuscripts as we now have them are commonly incomplete, disordered, with material added and lost. Second, it focuses the reader's attention on the consequences of these changes to the original manuscript: in the case of Hengwrt, the shift of three quires, the addition of a single sheet and the addition of a whole quire. These consequences may turn out to be significant for our understanding of the text. Consider the case of the added folio after I 27. The Merchant's Tale finishes on folio I27V and folio I 28r starts with line $\mathbf{z} 3$ of the Franklin's Tale, written in the same ink as the end of the Merchant's Tale. Notably, there is exactly enough space on I27V at the end of the Merchant's Tale to contain the first twelve missing lines of the Franklin. One may reason that the scribe did not write these twelve missing lines immediately because they were not available. The scribe knew that he needed to leave space for exactly twelve lines, and did so, continuing with the thirteenth line on the next folio ( $28 \mathrm{r}$ ).

And then, something very odd happens. It appears that at some later point, those twelve lines did become available to the scribe. But not only those twelve lines: a linking passage clearly intended to follow the Merchant also became available to the scribe. There was not sufficient space to include both the twelve lines and the linking passage at the base of $\mathrm{I} 27 \mathrm{v}$, and so the scribe wrote both on a single sheet and inserted 
it in the manuscript after folio I27. We label this sheet as I 27a, because it appears after the original I27. The ink in which this page is written is markedly paler in color than the ink on the surrounding folios. We see this paler ink elsewhere in the manuscript, in sections which appear written late in the manuscript's construction. What one does not see immediately, but which closer analysis shows, is that it appears that the original text of the link suggested that the next tale following the Merchant's Tale should be the Squire's Tale, not the Franklin's Tale, as is the case in most other manuscripts. ${ }^{15}$

Here, our new foliation indicates immediately to the reader that there is a problem. The reader is motivated to investigate: and finds evidence of what was available to the scribe at various times and what the scribe did with it. The traditional foliation, which numbers these three folios in simple numeric sequence, shows none of this. Of course, refoliation as we have done it can only be carried out when you have very full evidence of the manuscript. You need to know the quiring of the manuscript: that is how we are able to say that the ten folios which we label as I37a I through Io form a complete quire, and how we are able to say that this additional quire is placed at the centre of an existing quire of six, thereby making an irregular quire of I6. You also need to know exactly what text is on each page. This allows us to correlate missing text with missing pages- or the reverse, indeed. In several cases, we are able to identify a manuscript that has disordered text but no apparent disorder in the foliation. In these cases it appears that the manuscript's exemplar had its folios jumbled, so disordering the text, and the scribe simply copied what was in the exemplar even though it made no sense. ${ }^{\mathrm{I}}$

One could have carried out such a refoliation in days before the digital revolution. Indeed, the great Chaucer scholar Henry Bradshaw refoliated the much-damaged Canterbury Tales manuscript Cambridge Gg.4.27 in this way in the nineteenth century. However, in the time when few people looked at the manuscripts themselves, and when those few were likely to be scholars with a good understanding of what they were looking at, one might argue that there was little benefit in a refoliation such as that executed by Bradshaw. But now, manuscripts are appearing all over the web, and many of the people who are looking at them are new to their study. We know far more about the manuscripts, partly because of the improved access to digital images, and partly because we are now transcribing more and more manuscripts. A huge help for us in our refoliation was the decades of work done by Dan Mosser towards his 
Catalogue of the Manuscripts and Incunables of the Canterbury Tales. ${ }^{17}$ Here again: the digital world is leading us to change what we do.

\section{Elements of a revolution: changing what we make}

Because of digital methods more of us now transcribe manuscripts than ever before, we look at manuscripts in ways we never did before, we may enumerate their pages and construction in new ways. You may argue, and I would agree, that desirable and useful as these changes may be, this falls someway short of a revolution. A great number of editions are still being made without transcription of manuscripts, and certainly requiring no refoliation of the manuscripts. Even if many more people were transcribing and refoliating manuscripts, still this may not amount to a revolution. I remarked earlier that we could count something as a revolution if it changed what we do, what we make, and how we are. Changing what people do, how people work, would be no revolution if it meant that people are still making the same things.

However, some have argued that the digital world is bringing us a new kind of edition. The ease and excellence of digital imaging, and the accompanying interest in manuscript transcription, has given rise to what Elena Pierazzo calls "documentary digital editions", or Keirnan "image-based scholarly edition". ${ }^{18}$ In the last decades, a small cottage industry has sprung up around the transcription of manuscripts into digital form. We may see this with the list of digital editions maintained by Patrick Sahle at http://www.digitale-edition.de/. Many of these editions are what one might call digital facsimile transcripts, focussing on a single manuscript and recording its text in precise form, page by page, line by line and character by character. These editions - and they most certainly are editions, in the basic sense that an editor is scrutinizing every mark on the page - characteristically focus on two elements: the exact disposition of the text on each page and on the writing process. The first of these corresponds to "diplomatic" or "facsimile print" editions, the second to "genetic editions". Both kinds of edition are, of course, well established in the print world. We can date the first to the midnineteenth century, with such exemplars as Tischendorf's facsimile print transcript of Codex Sinaiticus. ${ }^{19}$ We could go back even earlier, to the handwritten facsimile copies of Ari hin Frodi's Islendinga bok, made by Jon Erlendsson around I65I. ${ }^{20}$ We can date the second to the initiatives of Louis Hay, which sparked the "critique genetique" movement which in turn found an institutional home in ITEM, with parallel streams 
of activity showing themselves in the transcription of the authorial manuscripts of Joyce, Beckett, Melville and Nietsche, among others. ${ }^{21}$ This catalogue of historical precedents suggests that, in itself, this move to "digital documentary editing" is not as revolutionary as some of its proponents claim. One might argue, that all these editions do is present familiar objects in digital form. Even if it were revolutionary, one might argue that the revolution is potential, as yet unrealized, and liable to fizzle to nothing after all: yet another utopian dream wrecked on cold reality. The editions listed by Sahle are impressive. But when we consider the number of editions produced by TUSTEP and Classical Text Editor (see above), and recall that the major scholarly publishers among them have published many times this number of scholarly editions over the years (459 listed at http://www.oxfordscholarlyeditions.com/. Over I 500 at http://www.brepols.net/, searching for "edition") this number looks less impressive. Further, a number of the editions listed by Sahle appear as effectively self-published, appearing on a university website and so hostages to the shifting policies of that university. Browsing through these editions reveals broken links, browsers which do not display as one might expect, or editions which are no more than electronic equivalents of a print publication. There are imaginative and remarkable projects here; and there are many which are not. In the context of the wide world of scholarly editions, the editions listed by Sahle appear as an insurgency. As with all revolutions, the insurgents display various levels of intensity, commitment and achievement. But these insurgents have not seized power.

I noted above that Elena Pierazzo argues that these are a new kind of edition: she calls them "a new type of editorial object", which she labels as a "documentary digital edition" (elsewhere, she calls them "digital documentary editions") and which she says record "as many features of the original document as are considered meaningful by the editors, displayed in all the ways the editors consider useful for the readers including all the tools necessary to achieve such a purpose". ${ }^{22}$ First, the core transcripts at the centre of these editions appear like nothing so much as diplomatic editions, well-known to textual scholars for centuries. Gregory Pass defines a diplomatic edition as "an edition (in print or online) of an historic manuscript text that seeks to reproduce as accurately as possible in typography all significant features of the manuscript original, including spelling and punctuation, abbreviations, deletions, insertions, and other alterations". ${ }^{23}$ This describes rather well the digital transcripts listed by Sahle and described by Pierazzo. 
The difference is that Pass is describing print books while Pierazzo is describing digital materials, and Pierazzo also includes tools and variant views in her description. Thus, typically, a digital transcript might offer alternative ways of seeing the text, toggling abbreviation on or off. However, there are rather few other tools offered by the actual digital editions listed by Sahle. They usually offer a search tool, they sometimes offer the facility to see the text and image side by side (a surprising number do not): that seems to be all. You can navigate from page to page; there might be indices of various kinds. But you can do these things with print editions too.

Indeed, these digital editions as described by Pierazzo, including the Jane Austen manuscript edition for which she had considerable responsibility, are surprisingly inert. You can view the transcription and image page by page, you can move from page to page, exactly as you can for a print edition. As in a print edition, there is one interface, that provided by the production team, and only one. We are offered a diplomatic view only of the text, and that is all. In a comparison of this edition with a print edition, this edition does not come off very well. It is in its favour, that it is free on the internet. But some of the things one might expect of a print edition - particularly, a table of contents detailing exactly what is in each manuscript volume- are absent from this digital edition. Nor do we find compensation in other areas. One might expect to be able to read either of the two chapters of Persuasion given here as a continuous text, without having to flick from page to page. Or one might want to load the text of a chapter into another system, a PDF viewer for instance, to read, annotate or print. You cannot do that either. In all, this looks like an uneasy compromise: it has some things a print edition might not have and some things a digital might have, while missing other things print and digital editions might have.

Not much revolution here, one might say. Indeed, one would expect a diplomatic edition in digital form is not going to be very different from one in print form. However, there are other kinds of edition: particularly, editions of texts in many manuscripts. Unsurprisingly, these are very rare among the editions listed by Sahle, which are almost all editions based on single witnesses. However, some have been made. My own editions of the Canterbury Tales, Prue Shaw's editions of the Dante, the transcripts of the Piers Plowman Electronic Archive and the Birmingham/Münster editions of the Greek New Testament are editions of texts which exist in multiple witnesses. Let us look at Prue Shaw's edition of Dante's Commedia, which may reasonably be seen as 


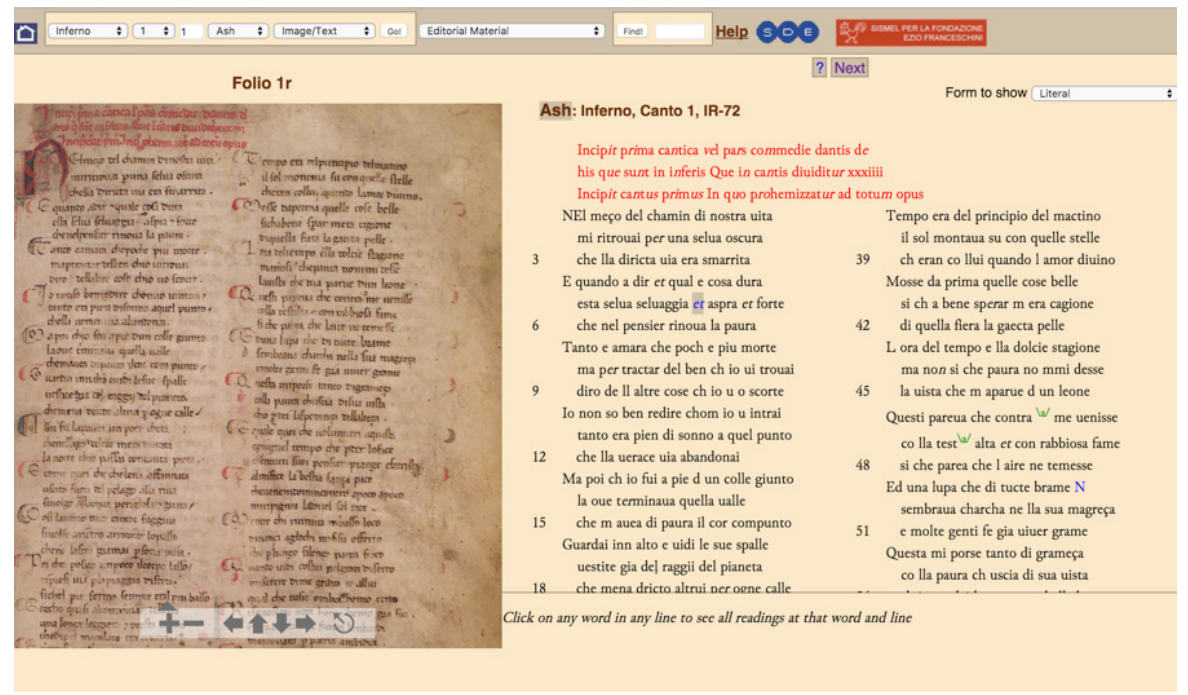

Figure 6. The Shaw edition of Dante's Commedia, showing the first page of the Ashburnham manuscript

the most fully conceived and realized digital edition of a text in many versions. ${ }^{24}$

At first, this looks like another of the many single witness image plus transcription we have discussed. We open with an image of the manuscript on the left and a transcription of the manuscript page on the right. We see that the transcript offers multiple views: we can look at a transcription of the text as it literally appears, or as first written by the scribe, or after any of multiple layers of correction. Further, this is not just one witness: there are seven manuscripts, and the full text of two editions. However, this edition is considerably more than a set of transcripts of the seven manuscripts. Probe further: we find a word-byword collation of the seven manuscripts and two editions, thus.

We see among other things that this collation includes information about the various layers of copying in the manuscripts. This collation is given for all 95,000 words in the 14,223 lines of the Commedia, and allows us, at every word, to see how the seven manuscripts and two editions agree. Note too that this collation is fully regularized: that is, variation in spelling has been filtered out so that the collation presents only variants with likely stemmatic significance.

This edition does not only include a collation. Clicking on the 'VMAP' symbol beside lines the collation brings up what we call a variant map. 


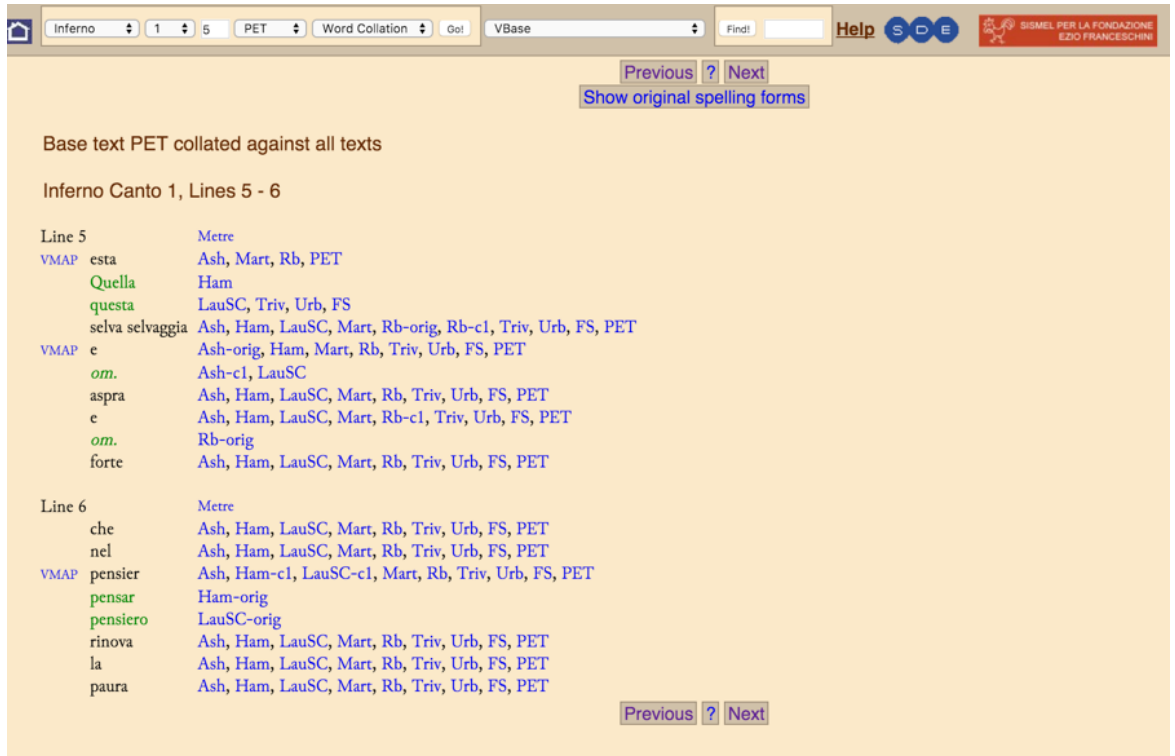

Figure 7. The word-by-word collation of two lines of Dante's Commedia, from Shaw's edition

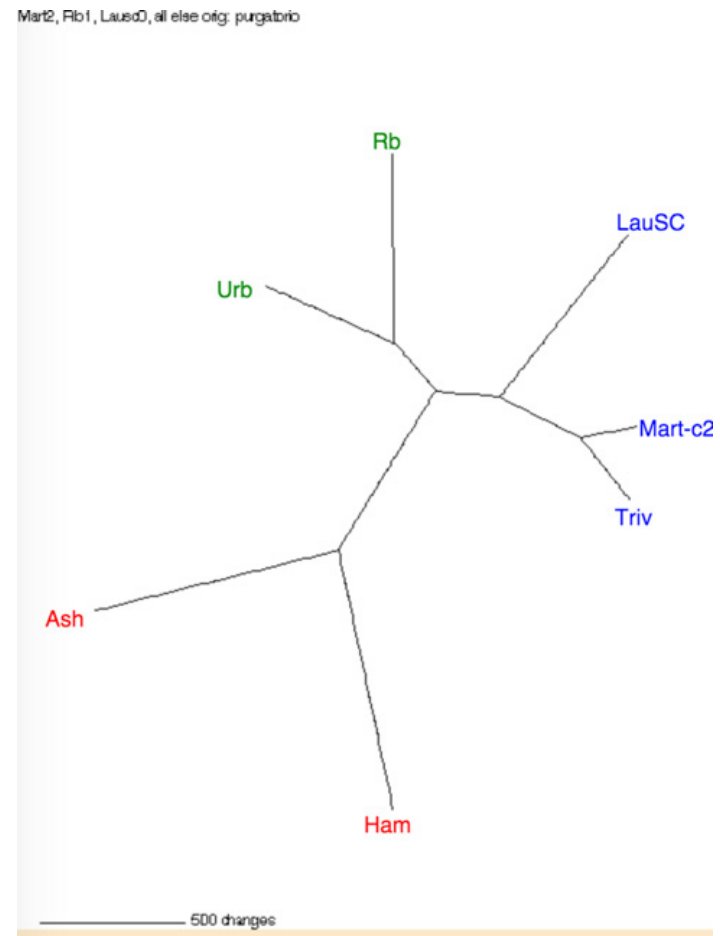

Figure 8. The variant map for Purgatorio I 8, 57: "e de primi appetibili" 
This resembles a stemma, in that it appears to group manuscripts and texts in some kind of tree-like relationship: thus Mart/Triv, Urb/Rb and Ash/Ham appear to form three distinct pairs. ${ }^{25}$ Where does this diagram come from? The extensive introductions provided by Shaw and others explain that this diagram was made by phylogenetic software, developed for evolutionary biology, which creates a hypothesis of the family relations among the manuscripts based on the readings they share and do not share in the collation. Throughout the introduction, Shaw examines the evidence provided both by phylogenetic and traditional philological methods. In I964, the great Dante scholar Giorgio Petrocchi produced a stemma of the relations among the early manuscripts of the Commedia. ${ }^{26}$ In 2000 , Federico Sanguineti challenged Petrocchi's stemma, alleging that the single manuscript at the top left of Figure 8, Urb, was independent of all other mss of the Commedia and therefore equivalent in authority to all the other 800 manuscripts of the Commedia. ${ }^{27}$ One can read in the editorial material Shaw's careful demolition of Sanguineti's arguments. Further, the reader can test in the collation, in the variant maps, and in the variant database tool provided by Shaw, whether Shaw is right. Here is the core evidence of the common descent of Urb and another manuscript, $\mathrm{Rb}$, which validates Petrocchi against Sanguineti, in the form of some 300 variants identified by the VBase search tool as likely to have been present in the shared ancestor of Urb/Rb.

Yet, there is one thing missing from Shaw's edition. She does not provide her own edited text. This absence strikes me as the single most remarkable element of the edition. It shifts the focus away from the editor, as maker of a text, to the documents themselves and what we might learn from them. The centre of the edition is not the product: the edited text, with all else seen as ancillary, preparatory, and explanatory. The centre of the edition is process: the search for understanding of all these documents and how they relate to each other. Nor is Shaw alone in this view of an edition in the digital age, as not requiring an edited text. Our editions of sections of the Canterbury Tales also lack an edited text. While the Nestle-Aland Greek New Testament text can be found within the Greek New Testament edition websites at Münster and Birmingham, it is almost invisible, indeed irrelevant. The absence of an edited text from both the Shaw edition and the Greek New Testament sites declares clearly: the aim of these editions is something other than the establishment of a text.

If an edition no longer needs an edited text, one might ask: why do we need an edition? 


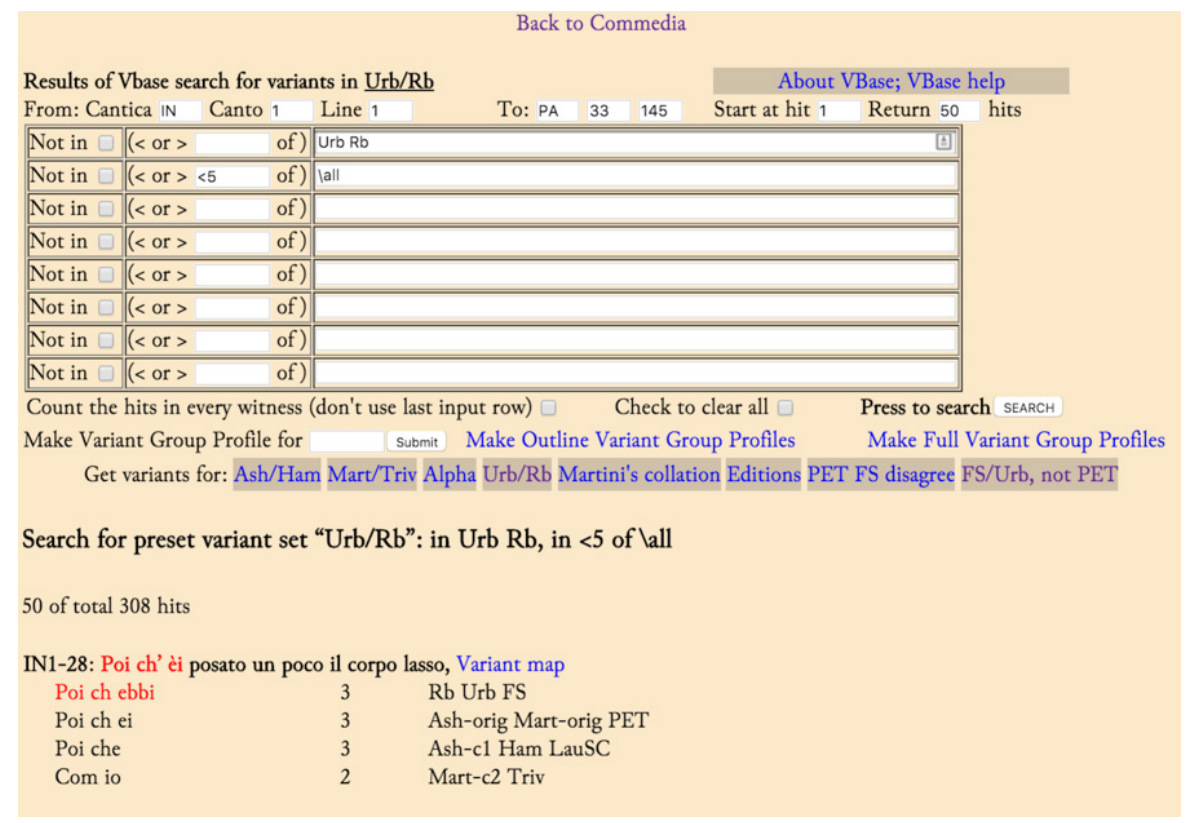

Figure 9. VBase search for $\mathrm{Urb} / \mathrm{Rb}$ variants

In the midst of this confusion of documents, one might also ask: where is Dante, and the work we know as the Commedia? F.W. Bateson asked: if the Mona Lisa is in the Louvre, where is Hamlet? ${ }^{28}$ The best answer for this that I know (and it is not Bateson's answer) is that Hamlet is in all the documents, all the versions, all the performances of Hamlet, and in the minds of all who have ever encountered Hamlet. There is no one Hamlet, no one Commedia, no one definitive text we can point at and say, this is what Dante wrote. Yet: we still think of something we call the Commedia. This has led several scholars to ask, from different directions, what do we mean by the term "work" in the digital age, for example in the essays in a recent number of Ecdotica edited by Barbara Bordalejo, with articles by her, Paul Eggert, Peter Shillingsburg, Hans Gabler and myself. ${ }^{29}$ Here is the definition I offer of a "work" in that collection: the work is the set of texts which is hypothesized as organically related, in terms of the communicative acts which they present. In this definition, the task of an editor of the Commedia is to identify the documents which witness the communicative act we call the Commedia, and then to define how all the documents are related to each other and what each tells us of the Commedia, as Shaw does. In this definition, the Commedia is grounded in the seven manuscripts and 
two editions Shaw studies. These manuscripts, the documents Shaw hypothesizes, the relations she uncovered among the documents and all involved in their creation, transmission and reception, and the acts of communication we extract from them: these are the Commedia.

This redefinition of the edition amounts to a considerable expansion. An edition, it follows, is not just the production of a text. It is a narration of the whole history of a work, from its conception, through its production and first and later publication, and then its reception among all its readers right to the present. This could be an enormous task. Exactly one such edition has been produced: Paul Eggert's edition of the Australian writer Henry Lawson's short story collection "While the Billy Boils". ${ }^{\circ}$ Eggert is able, on his own, to create such an edition for this one book, telling its whole history. But to do this for a work the size of the Commedia, with its influence stretching over centuries into almost every corner of our culture - no one scholar could ever do that. Indeed, no one scholar could ever achieve the first and most basic task of such an edition, the transcription of all the manuscripts, their collation and analysis. With considerable funding and help, and huge individual effort, Shaw was able to do this for just seven manuscripts, and it took fifteen years. How long would the full 800 manuscripts take?

\section{Elements of a revolution: changing who we are}

Now finally, we arrive at what I believe may be truly revolutionary about the impact of the digital age on scholarly editing. Every edition I have discussed so far has been made according to what we might call the Alexandrian consensus. The librarians gathered the many texts of Homer together; the scholars studied them and created a text; a grateful world took that text and read it. ${ }^{3 \mathrm{I}}$ This model rests on two pillars. The first pillar is that only qualified scholars may examine the primary documents. The second pillar is that only qualified scholars have the authority to make a text the rest of us may read. Both pillars are now fallen. We are moving to a world where every manuscript and every book from the past is online, free for anyone to look at. You no longer need to be tenured and well-connected to see a manuscript: increasingly, all you need is an internet connection. As for academic authority: peer-review and tenure committees are fine things but no-one is going to assert that only approved scholars can read manuscripts. If anyone doubted this, the Transcribe Bentham and similar projects has shown that transcriptions of even very demanding material can be made by people without formal training. ${ }^{32}$ 
Here is what we have: we want to make editions based on all the manuscripts, possibly hundreds, even thousands of them. We want to trace the history of a work through all its manifestations: every publication, every version. The materials are available free online to everyone. We do not have enough students and scholars to do this work within the academy. We know there are interested and committed people who can help us. So let us thrown open the doors, and invite others to join us. "Crowdsourcing" is the word of the moment: writing encyclopedias, correcting newspaper transcripts, and now scholarly editing. These are tasks for the wisdom of crowds.

Indeed, we need people to help us. Several major projects, including our own, are experimenting with opening up our work to others. We could do this in two ways. We could say to people: give us your work, and we will use it as we wish. Or we could say: we will work together and anyone can use what we make. The difference is small, it seems: but critical. Traditionally, we scholars like to own and control what we make. This is my edition. I want to control how it is used. You may contribute, but I will control what you contribute. In the world of print, where the target was a fixed printed object distributed by a publisher who was happy to hold the exclusive license for your edition, this was a fortunate coalescence of interests.

But in the digital world, that attitude cripples. I make my digital edition, I create a beautiful interface for it, then I wrap it up in copyright and other licensing restrictions so that it can only be used in the ways, and even by the people, whom I approve. There are numerous problems with this. First: who is going to maintain that interface, that edition, when you are no longer there, or you have run out of funding? What happens to all those carefully made transcripts, all that work? Second: why would people want to contribute to your edition, when you are going to control their work- so that they might even lose access to their own work? There are other arguments too: one might question the morality of work done with public support, as is the case for virtually all editions, becoming effectively the private property of the editors.

It is for these reasons that we, and several others, argue that we should publish the base materials of our editions - particularly the transcripts and the images - under the Creative Commons Attribution licence. Indeed we should go further than that. We should make it as easy as we can for others to take what we have made, to adapt it and augment it in any way they wish, and then republish it. And that includes commercial publishers. If they can take what we have made and publish it and make 
money from it, excellent. In this world, our transcripts of Canterbury Tales manuscripts would appear in many places across the web. Some scholars might add annotations to them, links to other materials, commentaries, glossaries. Others might alter them for their own purposes. Instead of our own, single, monolithic edition, there would be a flourishing ecoculture of overlapping sites, using our material in multiple ways, each finding their own readership. I have to say that persuading scholars to relinquish control of what they have made is not easy. We have been trained, since our first undergraduate days, to regard our research as dragons value their gold: of more value if we hoard it than if we spend it. But in the digital world, giving and taking is all that matters.

And, there are people, many, many of them, who want to take what we make. I have mentioned the Codex Sinaiticus website: within the first four months of the sites launch, over I.25 million people visited it. Less spectacular perhaps, but equally impressive, are the figures for Barbara Bordalejo's online Variorium edition of Darwin's Origin of Species: over the last two years, this has averaged a steady 500 users a month, with around thirty of those each month spending more than half an hour looking at the site. ${ }^{33}$ And here, too, is our view of how we might bring the Canterbury Tales, its text, manuscripts, and performance, to the born-digital generation. We call this the CantApp:

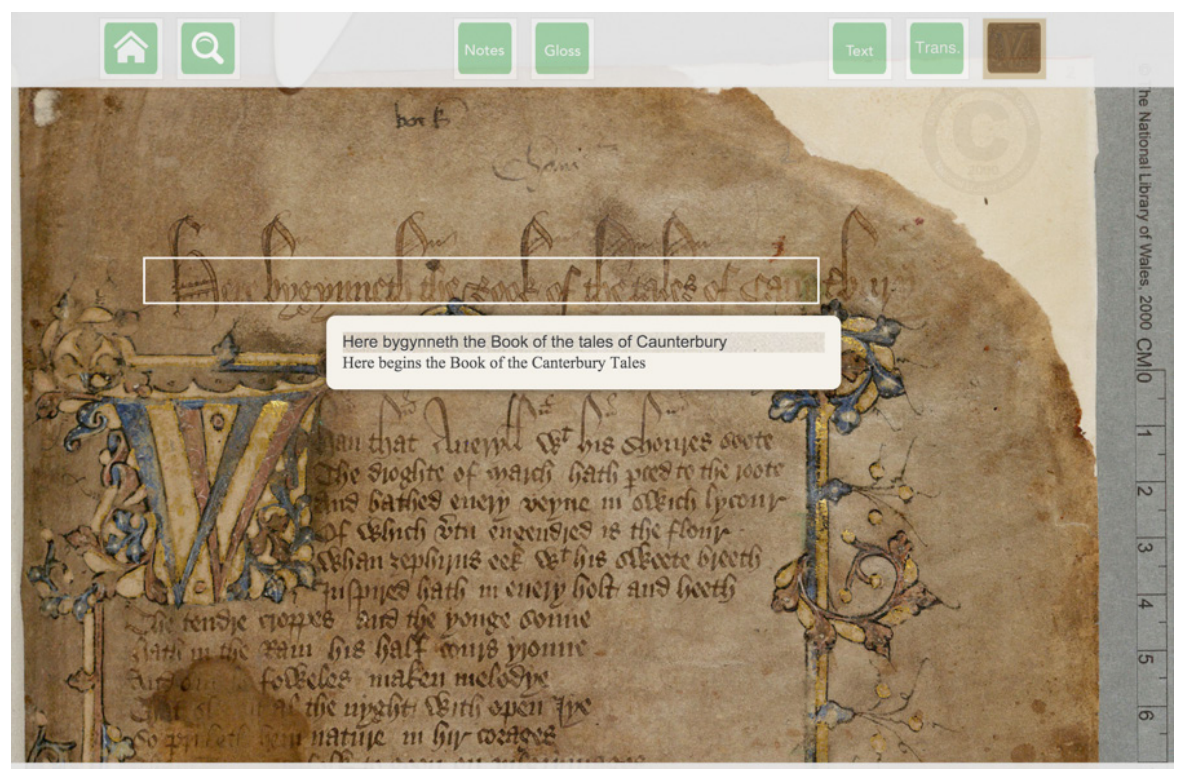

II

Figure 10. The CantApp, opening page 
Bordalejo's Darwin Variorum could not have been made without the work of others before her; we should like our CantApp to inspire others to take our work and do better. We all know the topos that we are standing on the shoulders of the scholars who have preceded us. The digital age offers a variant on this. As well as stand on the shoulders of others, we should help others to stand on our shoulders. This will change who we are. Now, that would be revolutionary.

\section{Notes}

I. Among many essays and books incorporating (while sometimes criticizing) this meme, see Jerome McGann, Radiant Textuality (New York: Palgrave, 200I); pages 53-74 reprint his essay 'The Rationale of Hypertext', originally published online in 1995 and available at www2.iath.virginia.edu/public/ jjm $2 \mathrm{f} / \mathrm{rationale}$ html and in print in Electronic Text: Investigations in Method and Theory, ed. by Kathryn Sutherland (Oxford: Oxford University Press, 1997); Digital Critical Editions, ed. by Daniel Apollon, Claire Bélisle and Philippe Régnier (Urbana, Chicago and Springfield: University of Illinois Press, 20I4): Tara Andrews, 'The Third Way: Philology and Critical Edition in the Digital Age', in Variants Io, ed. by Wim Van Mierlo (Amsterdam and New York: Rodopi, 2013).

2. Roger Boesche, Tocqueville's Road Map: Methodology, Liberalism, Revolution, and Despotism (Lanham, MD: Lexington, 2006), pp. 86-87.

3. There is a full print facsimile of the Beowulf manuscript edited by Julius Zupitza, Beowulf. Autotypes of the unique Cotton ms. Vitellius A XV in the British Museum, with a transliteration and notes (London: N. Trübner, for the Early English Text Society, I882; reprinted in I959 and I969). A single page of the manuscript, fol. I60v, is reproduced as Figure I of the most widely used edition of Beowulf: Klaeber's Beowulf and the Fight at Finnsburgh. Fourth Edition, ed. by R. D. Fulk, Robert Bjork and John D. Niles (Toronto, Buffalo, London: University of Toronto Press, 2008).

4. Electronic Beowulf 4.0, ed. by Kevin Kiernan (University of Kentucky, 201 5), at http://ebeowulf.uky.edu/ebeo4.o/start.html [accessed 3I October 20I 5].

5. Personal communication, Scott McKendrick, British Library. The digital edition is http://www.codexsinaiticus.org/ [accessed 3I October 20I5].

6. A.S.G. Edwards paper, delivered in a Master Class at the Centre for Textual Scholarship at De Montfort University on I June 2006; reported by Peter Shillingsburg, 'How Literary Works Exist: Convenient Scholarly Editions', Digital Humanities Quarterly, 3:3 (2009) \#I 8, at http://www. digitalhumanities.org/dhq/vol/3/3/000054/000054.html [accessed 3I October 
20I 5]. See too Edwards' critique of digitization in 'Back to the Real?', Times Literary Supplement 7 June 20I3, where he argues (inter alia) that success of digitization in reaching many readers (e.g. the ro, 000 hits a month on the Codex Sinaiticus website) is not scholarship but "a new branch of the entertainment industry.”

7. Emma Beer, 'Waking up in the British Library', Ariadne, 43 (2005), at http:// www.ariadne.ac.uk/issue 43/wakingupinbl-rpt.

8. Kenneth M. Price, 'Edition, Project, Database, Archive, Thematic Research Collection: What's in a Name?', Digital Humanities Quarterly, 3:3 (I009), at http://www.digitalhumanities.org/dhq/vol/3/3/000053/000053.html.

9. For TUStep: see the list at http://www.tustep.uni-tuebingen.de/ed3.html, numbering over 900 volumes; for Classical Text Editor, see the list at http:// cte.oeaw.ac.at//?ido=pub, for some I 50 volumes.

ıо. Thomas Tanselle, 'Foreword', in Electronic Textual Editing, ed. by Lou Burnard, Katharine O'Brien O'Keefe and John Unsworth (New York: Modern Language Association, 2006), pp. I-6 (p. 6); Barbara Bordalejo, 'The Texts We See and the Works We Imagine', Ecdotica, I3 (20I3), pp. 64-75 (p. 75).

II. One can index the difficulty of manuscript transcription from the proliferation of articles, manuals and guides over the last decades. A few examples: my own attempt, with Elizabeth Solopova, to define protocols for manuscript transcription for the manuscripts of the Canterbury Tales, in "Guidelines for Transcription of the Manuscripts of the Wife of Bath's Prologue"; see too Alois Pichler's argument that "Texts are not objectively existing entities which just need to be discovered and presented, but entities which have to be constructed in "Advantages of a Machine-Readable Version of Wittgenstein's Nachlass", p. 774. Pichler's view (which is effectively identical to mine and Solopova's) is attacked by Renear as "anti-realist": see the account of the discussion in my "What Text Really is Not, and Why Editors have to Learn to Swim". The distinction between levels of transcription is also discussed by Barbara Bordalejo in "The Commedia Project Encoding System". See also, among many others: the "Basic Conventions for Transcription" for the Scriptorium project at http://scriptorium.english.cam.ac.uk/handwriting/ materials/conventions/; the CENDARI project guide at http://www.cendari.eu/ sites/default/files/ARGTranscriptions.pdf; and many more.

I 2. The whole manuscript is online at https://www.llgc.org.uk/?id=257; the first page is there numbered as "folio $2 r$ ".

I3. You can read about our efforts to answer these questions in the Canterbury Tales Project blog and wiki, at www.textualcommunities.usask.ca, a discussion informed by the conflicting perspectives presented by the studies referred to in footnote II. 
I4. Recording of these lower-level "graphetic" features of scribal writing (the different forms of each letter, indeed of each stroke) might be useful for the making of "scribal profiles" as advocated by Angus McIntosh, 'Scribal Profiles from Middle English Texts', Neuphilologische Mitteilungen, 76 (I975), 2I8-235.

I 5. This explanation follows that given by John Manly and Edith Rickert, The Text of the Canterbury Tales: Studied on the Basis of All Known Manuscripts, 8 vols (Chicago: Univ. of Chicago Press, I940), I, 27I-272. Compare the discussion of these folios by Estelle Stubbs, 'Observations: Section IV', in The Hengwrt Chancer Digital Facsimile (Leicester: Scholarly Digital Editions, 20OI).

I6. For example: in Oxford New College MS 3 I 4 (Ne) the text of the Parson's Tale appears in the following order: segments I-98, 532-580, I62-273, 687$735,320-532,99-16$ I, 582-687, 273-320, 735-end. The shifts from sequence to sequence occur mid-page and mid-segment. Sense can be made of this if one presumes that in the ancestor copy of this tale the text of the seven segments 99-735 occupied three quires of eight. The first and last two leaves of the first quire (containing 99-I6I and 273-320) were swapped with the first and last two leaves of the third quire (containing 532-580 and 687-735) to give the order in which the Parson's Tale now appears in Ne.

I7. Daniel W. Mosser, A Digital Catalogue of the Pre-I50o Manuscripts and Incunables of the Canterbury Tales (Blacksburg VA: 2nd edn, Virginia Tech, $2013)$.

I8. Kevin Kiernan, 'Digital Facsimiles in Editing', in Electronic Textual Editing, ed. by Lou Burnard, Katherine O’Brien O'Keeffe and John Unsworth (New York: Modern Language Association of America, 2006), pp. 262-268; Elena Pierazzo, 'A Rationale of Digital Documentary editions', Literary and Linguistic Computing, 26 (201 I), 463-477.

I9. Constantin von Tischendorf, Bibliorum Codex Sinaiticus Petropolitanus, 4 volumes (Leipzig, I 862).

20. Vésteinn Ólason, Íslendingabøkur - The Books of The Icelanders, Richard and Margaret Beck Trust Lecture, University of Victoria (20 March 2003). At http://web.uvic.ca/ becktrus/assets/text/vesteinn_or.php.

2I. Jedd Deppman, Daniel Ferrer and Michael Groden, Genetic Criticism: Texts and Avant-textes (Philadelphia: University of Pennsylvania, 2004).

22. Pierazzo, 'Rationale', p. 475.

23. Gregory A. Pass, Descriptive Cataloging of Ancient, Medieval, Renaissance, and Early Modern Manuscripts (Chicago: Association of College and Research Libraries, 2003), p. I44. 
24. Prue Shaw, Dante Alighieri. Commedia. A Digital Edition. (Leicester and Florence: Scholarly Digital Editions and SISMEL, 2010).

25. Mart: Milan, Biblioteca Nazionale Braidense, Aldina AP XVI 25; Triv: Milan, Biblioteca dell'Archivio Storico Civico e Trivulziana, Ms. Trivulziano I080; Rb: Florence, Biblioteca Riccardiana, Ms. Riccardiano I005 and Milan, Biblioteca Nazionale Braidense, Ms. AG XII 2; Urb: Città del Vaticano, Biblioteca Apostolica Vaticana, Ms. Urbinate latino 366; Ash: Florence, Biblioteca Medicea Laurenziana, Ms. Ashburnham 828; Ham: Berlin, Staatsbibliothek zu Berlin Preußischer Kulturbesitz, Ms. Hamilton 203.

26. Dante Alighieri, La Commedia secondo l'antica vulgata a cura di Giorgio Petrocchi, Edizione Nazionale a cura della Società Dantesca Italiana, 4 vols (Milano: Arnoldo Mondadori Editore, I966-I967).

27. Dantis Alagherii, Comedia. Edizione critica per cura di Federico Sanguineti (Firenze: Edizioni del Galluzzo, 200I).

28. F.W. Bateson, 'Modern Bibliography and the Literary Artifact', in English Studies Today, ed. by Georges A. Bonnard (Bern: 2nd edn, Francke Verlag, I96I), pp. 67-77 (p. 70).

29. Peter M. Robinson, 'The Concept of the Work in the Digital Age', in Work, Text and Document in the Digital Age, ed. by Barbara Bordalejo, Ecdotica, Io (20I3), pp. I3-4I.

30. Paul Eggert, The Biography of a Book: Henry Lawson's While the Billy Boils (Philadelphia and Sydney: Penn State University Press and University of Sydney Press, 2013).

3I. L.D. Reynolds and N.G. Wilson, Scribes and Scholars: A Guide to the Transmission of Greek and Latin Literature (Oxford: 4th edn, Oxford University Press, 20I3), pp. 6-I6.

32. Tim Causer and Valerie Wallace, 'Building a Volunteer Community: Results and Findings from Transcribe Bentham', Digital Humanities Quarterly, 6:2 (2012), online at http://www.digitalhumanities.org/dhq/vol/6/2/000I 25/ oOOI $25 \cdot \mathrm{html}$.

33. Barbara Bordalejo, ed., Online Variorium of Darwin's Origin of Species (Darwin Online, 2009), at http://darwin-online.org.uk/Variorium/index. html.

\section{Bibliography}

Andrews, Tara, 'The Third Way: Philology and Critical Edition in the Digital Age', in Variants Io, ed. by Wim Van Mierlo (Amsterdam and New York: Rodopi, 20I3), pp. 6I-76 
Bateson, F.W., 'Modern Bibliography and the Literary Artifact', English Studies Today, ed. by Georges A. Bonnard (Bern: 2nd edn, Francke Verlag, I96I), pp. $67-77$

Beer, Emma, 'Waking up in the British Library', Ariadne, 43 (2005), at http:// www.ariadne.ac.uk/issue43/wakingupinbl-rpt

Beowulf: Klaeber's Beowulf and the Fight at Finnsburgh. Fourth Edition, ed. by R.D. Fulk, Robert Bjork and John D. Niles (Toronto, Buffalo, London: University of Toronto Press, 2008)

Boesche, Roger, Tocqueville's Road Map: Methodology, Liberalism, Revolution, and Despotism (Lanham, MD: Lexington, 2006)

Bordalejo, Barbara, ed., Online Variorium of Darwin's Origin of Species (Darwin Online, 2009), at http://darwin-online.org.uk/Variorium/index. html

Bordalejo, Barbara, “The Commedia Project Encoding System”, in Prue Shaw (ed.) Dante Alighieri: The Commedia. A Digital Edition. Birmingham: Scholarly Digital Editions and Florence: Sismel, 20 Io.

Bordalejo, Barbara, 'The Texts We See and the Works We Imagine', Ecdotica, I3 (2013), 64-75

Causer, Tim and Valerie Wallace, 'Building a Volunteer Community: Results and Findings from Transcribe Bentham', Digital Humanities Quarterly, 6:2 (2012), online at http:/www.digitalhumanities.org/dhq/ $\mathrm{vol} / 6 / 2 / 000 \mathrm{I} 25 / 000 \mathrm{I} 25 \cdot \mathrm{html}$

Dante Alighieri, La Commedia secondo l'antica vulgata a cura di Giorgio Petrocchi, Edizione Nazionale a cura della Società Dantesca Italiana, 4 vols (Milano: Arnoldo Mondadori Editore, I966-I967).

Dantis Alagherii, Comedia. Edizione critica per cura di Federico Sanguineti (Firenze, Edizioni del Galluzzo, 200I).

Deppman, Jedd, Daniel Ferrer and Michael Groden, Genetic Criticism: Texts and Avant-textes (Philadelphia: University of Pennsylvania, 2004)

Digital Critical Editions, ed. by Daniel Apollon, Claire Bélisle and Philippe Régnier (Urbana, Chicago and Springfield: University of Illinois Press, 20I4)

Edwards, A.S.G., 'Back to the Real?', Times Literary Supplement, 7 June 2013

Eggert, Paul, The Biography of a Book: Henry Lawson's While the Billy Boils (Philadelphia and Sydney: Penn State University Press and University of Sydney Press, 20I3)

Electronic Beowulf 4.o, ed. by Kevin Kiernan (University of Kentucky, 20I 5 ), at http://ebeowulf.uky.edu/ebeo4.o/start.html 
Electronic Text: Investigations in Method and Theory, ed. by Kathryn Sutherland (Oxford: Oxford University Press, I997)

Kiernan, Kevin, 'Digital Facsimiles in Editing', Electronic Textual Editing, ed. by Lou Burnard, Katherine O'Brien O'Keeffe and John Unsworth (New York: Modern Language Association of America, 2006), pp. 262-268

McGann, Jerome, 'The Rationale of Hypertext', Electronic Text: Investigations in Method and Theory, ed. by Kathryn Sutherland (Oxford: Oxford University Press, 1997), pp. 19-46

McGann, Jerome, Radiant Textuality (New York: Palgrave, 200I)

McIntosh, Angus, 'Scribal Profiles from Middle English Texts', Neuphilologische Mitteilungen, 76 (I975), 218-235

Manly, John and Edith Rickert, The Text of the Canterbury Tales: Studied on the Basis of All Known Manuscripts, 8 vols (Chicago: Univ. of Chicago Press, I940)

Mosser, Daniel W., A Digital Catalogue of the Pre-I50o Manuscripts and Incunables of the Canterbury Tales (Blacksburg VA: 2nd edn, Virginia Tech, 20I3)

Ólason, Vésteinn, Íslendingabakur - The Books of The Icelanders, Richard and Margaret Beck Trust Lecture, University of Victoria (20 March 2003), available at http://web.uvic.ca/ becktrus/assets/text/vesteinn_or.php

Pass, Gregory A., Descriptive Cataloguing of Ancient, Medieval, Renaissance, and Early Modern Manuscripts (Chicago: Association of College and Research Libraries, 2003)

Pierazzo, Elena, 'A Rationale of Digital Documentary Editions', Literary and Linguistic Computing, 26 (201 I), pp. 463-477

Price, Kenneth M., 'Edition, Project, Database, Archive, Thematic Research Collection: What's in a Name?', Digital Humanities Quarterly, 3:3 (2009), at http://www.digitalhumanities.org/dhq/vol/3/3/000053/000053.html

Reynolds, Leighton D. and Nigel G. Wilson, Scribes and Scholars: A Guide to the Transmission of Greek and Latin Literature (Oxford: 4th edn, Oxford University Press, 2013)

Robinson, Peter and Elizabeth Solopova, "Guidelines for Transcription of the Manuscripts of the Wife of Bath's Prologue", in The Canterbury Tales Project Occasional Papers, ed. by Norman F. Blake and Peter M.W. Robinson (Oxford: Office for Humanities Communication, 1993), pp. 19-52

Robinson, Peter M., 'The Concept of the Work in the Digital Age', in Work, Text and Document in the Digital Age, ed. by Barbara Bordalejo [=Ecdotica, IO (2OI3)], pp. I3-4I 
Shaw, Prue Dante Alighieri. Commedia. A Digital Edition. (Leicester and Florence: Scholarly Digital Editions and SISMEL, 20IO)

Shillingsburg, Peter, 'How Literary Works Exist: Convenient Scholarly Editions', Digital Humanities Quarterly 3:3 (2009) \# I 8, at http://www. digitalhumanities.org/dhq/vol/3/3/000054/000054.html [accessed 3I October 20I 5]

Stubbs, Estelle, 'Observations: Section IV', The Hengwrt Chaucer Digital Facsimile (Leicester: Scholarly Digital Editions, 200I).

Tanselle, Thomas 'Foreword', in Electronic Textual Editing, ed. by Lou Burnard, Katharine O'Brien O'Keefe and John Unsworth (New York: Modern Language Association, 2006), pp. I-6

von Tischendorf, Constantin, Bibliorum Codex Sinaiticus Petropolitanus, 4 volumes (Leipzig, I 862)

Zupitza, Julius Beowulf. Autotypes of the unique Cotton ms. Vitellius A XV in the British Museum, with a transliteration and notes (London: N. Trübner, for the Early English Text Society, I 882; reprinted in I959 and I969) 